\title{
METODE TUTOR SEBAYA UNTUK MENINGKATKAN HASIL BELAJAR MATEMATIKA PADA MATERI PENGOLAHAN DATA
}

\author{
MAMAN AHDIYAT \\ mamanahdiyat@yahoo.co.id \\ Program Studi Pendidikan Matematika,Fakultas Teknik, Matematika, dan IPA \\ Universitas Indraprasta PGRI
}

SARJAYA

Guru SDN Sukasari 3 Tangerang

\begin{abstract}
Abstak. Metode Tutor Sebaya untuk meningkatkan hasil belajar Matemetika pada materi pengolahan data. Penelitian ini bertujuan untuk (1). Mengetahui hasil belajar matematika siswa yang diajar menggunakan metode tutor sebaya (2). Mengetahui secara empiris pengaruh penerapan metode tutor sebaya terhadap hasil belajar matematika. Metode penelitian yang digunakan adalah eksperimen, Hasil analisis dan uji hipotesis diperoleh. terdapat perbedaan hasil belajar matematika antara siswa yang diajar menggunakan metode tutor sebaya dengan siswa yang diajar menggunakan metode ceramah.
\end{abstract}

Kata Kunci: Metode tutor sebaya, Metode Ceramah, Hasil belajar matematika.

Abstract. By using Methodology of peer tutoring is to increase the result of mathematics study on statistic at sixth grade of elementary school This research is aimed (1) To know the result of mathematics study on tutor methodology (2) To know empirical of the effected of peer tutoring to mathematics study result. The research has been using experiment. The hypothesis result found that, there is deferent between using of tutor and lecture methodology.

Keywords: Peer Tutoring, Lecture, Mathematics study result

\section{PENDAHULUAN}

Pendidikan merupakan kebutuhan yang sudah tidak dapat dipisahkan dari kehidupan manusia, karena dengan pendidikan dapat meningkatkan kualitas sumber daya manusia. Dengan pendidikan pula kita dapat mengetahui apa yang tidak tahu menjadi tahu. Pendidikan merupakan sarana untuk menuntut ilmu pengetahuan yang nantinya dapat bermanfaat dalam hidup dan kehidupan manusia.

Pendidikan senantiasa dituntut untuk mengadakan penyesuaian dan perubahan ke arah yang lebih baik sehingga diharapkan adanya inovasi-inovasi dalam bidang pendidikan. Salah satu inovasi dalam bidang pendidikan adalah penyesuaian/ relevan metode mengajar agar dapat menjamin tercapainya tujuan program pembelajaran/ pendidikan.

Suatu metode dapat dikatakan relevan, jika metode tersebut dapat mengantarkan siswa mencapai tujuan umum pendidikan adalah "kedewasaan" (Sadulloh, 2009:85). Dalam Undang-Undang Republik Indonesia Nomor 20 Tahun 2003 tentang Sistem Pendidikan Nasional, mengenai fungsi dan tujuan pendidikan sebagai berikut: "pendidikan Nasional berfungsi mengembangkan kemampuan dan membentuk watak serta peradaban bangsa yang bermartabat dalam rangka mencerdaskan kehidupan bangsa, bertujuan untuk berkembangnya potensi peserta didik agar menjadi manusia yang beriman dan bertakwa kepada Tuhan Yang Maha Esa, berakhlak mulia, sehat, berilmu, 
cakap, kreatif, mandiri, dan menjadi warga Negara yang demokratis serta bertanggung jawab."

Salah satu mata pelajaran yang akan diteliti oleh penulis yaitu mata pelajaran matematika. Matematika merupakan ilmu tentang berpikir "Sains of thinking" (Solso, dkk. 2005:418-419). Mata pelajaran matematika merupakan salah satu aspek yang penting diajarkan kepada siswa di sekolah, mulai dari tingkatan SD, SMP, dan SMA serta perguruan tinggi. Banyak faktor yang memengaruhi keberhasilan siswa dalam mempelajari pelajaran matematika dalam proses belajar dan mengajar (PBM) di kelas. Dengan berbagai alternatif pendekatan, mulai dari metode mengajar sampai penggunaan alat peraga. Seorang guru yang baik harus mampu menyusun suatu strategi pembelajaran yang mampu membawa peranan agar siswa aktif dalam belajar (Sutarsih. 2009:7). Hal ini bukan semata-mata untuk memenuhi kewajiban siswa mempelajari matematika tetapi didasarkan atas kesadaran dan ketertarikan siswa untuk mempelajari matematika.

Sehubungan dengan hal itu, tenaga pendidik (guru) haruslah disiapkan untuk memenuhi layanan interaksi dengan siswa, seperti diamanatkan oleh Undang-Undang Nomor 14 Tahun 2005 tentang Guru dan Dosen pasal 1 ayat 1 bahwa "Guru adalah pendidik professional dengan tugas utama mendidik, mengajar, membimbing, mengarahkan, melatih, menilai, dan mengevaluasi peserta didik pada pendidikan anak usia dini jalur pendidikan formal, pendidikan dasar, dan menengah."

Untuk mewujudkan tujuan ini sangat dibutuhkan peran serta guru sebagai pengelola proses pembelajaran. Selaku fasilitator hendaknya berusaha menciptakan kondisi pembelajaran yang kondusif. Guru diharapkan mampu memberikan rangsangan kepada siswa untuk meningkatkan prestasi belajar matematika (Sutarsih. 2009:5).

Metode pembelajaran satu arah di mana siswa hanya ditempatkan sebagai objek dan membatasi siswa dalam berperan aktif dalam kegiatan belajar sehingga siswa menjadi malas dan kurang bersemangat dalam mengikuti pelajaran matematika (Masitoh dan Dewi. 2009:5). Guru hanya menerapkan metode ceramah, menjelaskan kemudian memberi tugas kepada siswa. Siswa yang memahami materi yang diajarkan oleh guru akan dapat mengerjakan tugas tersebut dengan baik tetapi siswa yang belum memahami materi yang diajarkan akan mengalami kesulitan bahkan hanya bercanda saja. Guru lebih mendominasi dalam kegiatan belajar mengajar, hal ini menyebabkan banyak siswa kurang berprestasi dalam pelajaran matematika sehingga tujuan atau kriteria ketuntasan minimal (KKM) yang ditetapkan tidak tercapai dengan optimal.

Dalam permasalahan ini, peneliti akan mencoba salah satu strategi pembelajaran kooperatif yang dapat digunakan dalam PBM yakni metode tutor sebaya (peer group). Metode ini diharapkan dapat memotivasi siswa dalam belajar bekerja sama (kooperatif), saling memberi semangat dan membantu rekannya yang kesulitan dalam menuntaskan keterampilan-keterampilan yang dipersentasikan oleh guru.

Strategi pembelajaran kooperatif adalah starategi pembelajaran yang di dalamnya mengkondisikan para siswa untuk bekerja sama di dalam kelompok-kelompok kecil untuk membantu satu sama lain dalam belajar. Strategi pembelajaran kooperatif merupakan strategi pembelajaran yang membantu siswa mempelajari isi pelajaran dan meningkatkan hubungan social antar siswa.

Dalam tutor sebaya guru hanya memberikan konsep-konsep pokok. Pengembangan dari konsep-konsep tersebut selanjutnya dilakukan oleh siswa dalam bentuk kelompok. Kelompok-kelompok tersebut kemudian mendiskusikan konsep jawaban dari soal-soal yang diberikan, memahami konsep-konsep pengerjaan secara bersama-sama dalam kelompok, sehingga siswa terlibat langsung dalam penguasaan materi matematika. Guru bukan lagi berperan sebagai satu-satunya nara sumber dalam 
KBM, tetapi berperan sebagai mediator, stabilisator, dan manajer pembelajaran (Masitoh dan Dewi. 2009:233).

\section{TINJAUAN PUSTAKA}

\section{Hasil Belajar Matematika}

Undang-Undang Republik Indonesia No. 20 Tahun 2003 tentang Sistem Pendidikan Nasional pasal 1 disebutkan bahwa "belajar adalah proses interaksi peserta didik dengan pendidik dan sumber belajar pada suatu lingkungan belajar".

Sedangkan sumber belajar berperan dalam menyediakan berbagai informasi dan pengetahuan yang diperlukan dalam mengembangkan berbagai kompetensi yang diinginkan pada bidang studi atau mata pelajaran yang dipelajarinya. Oleh karena itu sumber belajar yang beraneka ragam, di antaranya berupa bahan (media) pembelajaran memberikan sumbangan yang positif dalam peningkatan mutu pendidikan dan pembelajaran.

Definisi belajar menurut beberapa pakar pendidikan yang dikutip oleh Suprijono (2011:2) sebagai berikut :

a. Gagne

Belajar adalah perubahan disposisi atau kemampuan yang dicapai seseorang melalui aktivitas. Perubahan disposisi tersebut bukan diperoleh langsung dari proses pertumbuhan seseorang secara alamiah.

b. Travers

Belajar adalah proses menghasilkan penyesuaian tingkah laku.

c. Cronbach

Learning is shown by a change in behavior as a result of experience. (Belajar adalah perubahan perilaku sebagai hasil dari pengalaman).

d. Harold Spears

Learning is to observe, to read, to imitate, to try something themselves, to listen, to follow direction. (Dengan kata lain, bahwa belajar adalah mengamati, membaca, meniru, mencoba sesuatu, mendengar dan mengikuti arah tertentu).

e. Geoch

Learning is change in performance as a result of practice. (Belajar adalah perubahan performance sebagai hasil latihan).

f. Morgan

Learning is any relatively permanent change in behavior that is result of past experience. (Belajar adalah perubahan perilaku yang bersifat permanent sebagai hasil dari pengalaman).

Menurut Syaiful Bahri Djamarah dan Aswan Zain dalam bukunya yang berjudul Strategi Belajar Mengajar "Belajar adalah proses perubahan perilaku berkat pengalaman dan latihan. Artinya, tujuan kegiatan adalah perubahan tingkah laku, baik yang menyangkut pengetahuan, keterampilan maupun sikap, bahkan meliputi segenap aspek organisme atau pribadi. Kegiatan belajar mengajar seperti mengorganisasi pengalaman belajar, mengolah kegiatan belajar mengajar, menilai proses, dan hasil belajar, kesemuanya termasuk dalam cakupan tanggung jawab guru. Jadi, hakikat belajar adalah perubahan. (Djamarah dan Zain. 2006: 10)

Berdasarkan teori dan pendapat-pendapat di atas tentang belajar, bahwa belajar terkait dengan penekanan terhadap pengaruh lingkungan dan pengaruh yang dibawa sejak lahir. Secara genetik seseorang dilahirkan dengan sesuatu organ yang disebut kemampuan umum (intelegensi) yang bersumber dari otaknya. Otak yang dibawa sejak lahir itu terdiri dari dua belahan otak, yaitu otak kiri dan otak kanan (left hemisphere and right hemisphere). Kedua belahan otak tersebut mempunyai fungsi, tugas dan respon yang 
berbeda, serta seharusnya tumbuh dalam keseimbangan. Belahan otak kanan berfungsi menangkap keseluruhan yang bermakna, kreatif dan imajinatif, sedangkan otak kiri berfungsi untuk mengamati hal-hal yang logis, linear dan teratur. Kedua otak tersebut dalam pembelajaran sebaiknya berfungsi dalam keseimbangan. Jadi konsep belajar mengandung implikasi memfungsikan aspek nalar, logis maupun kreatif. Dengan kata lain dalam pembelajaran siswa membutuhkan stimulus atau rangsangan pada otak untuk mendapatkan respon yang positif.

Hasil belajar adalah pola-pola perbuatan, nilai-nilai, pengertian-pengertian, sikap-sikap, apresiasi, dan keterampilan. (Suprijono. 2011: 5)

Tujuan proses belajar mengajar pada hakikatnya adalah adanya perubahan tingkah laku yang diharapkan dapat dikuasai oleh siswa setelah menerima atau menempuh pengalaman belajar. Perubahan tingkah laku yang diharapkan dapat dikuasai siswa biasa disebut dengan hasil belajar. Perubahan-perubahan tingkah laku tersebut dapat berupa penguasaan ilmu pengetahuan, sikap, kebiasaan, tindakan atau keterampilan tertentu.

Kegiatan belajar mengajar, anak adalah sebagai subjek dan sebagai objek dari kegiatan pengajaran. Karena itu, inti proses pengajaran adalah kegiatan belajar anak didik dalam mencapai suatu tujuan pengajaran. Tujuan pengajaran tentu saja akan tercapai jika anak didik berusaha secara aktif untuk mencapainya. Keaktifan anak didik di sini tidak hanya dituntut dari segi fisik, tetapi juga dari segi kejiwaan. Bila hanya fisik anak yang aktif, tetapi pikiran dan mentalnya kurang aktif, maka kemungkinan besar tujuan pembelajaran tidak tercapai. Ini sama halnya anak didik tidak belajar, karena anak didik tidak merasakan perubahan dalam dirinya. Padahal belajar pada hakikatnya adalah "perubahan". (Djamarah dan Zain. 2006: 38)

Sudjana mengemukakan, "Hasil belajar adalah kemampuan-kemampuan yang dimiliki siswa setelah menerima pengalaman belajarnya". (Sudjana. 2004: 22)

Menurut Benjamin Bloom seperti yang dikutip oleh Sudjana, dapat diamati melalui tiga ranah yaitu :

a. Ranah kognitif : berkenaan dengan hasil belajar intelektual yang terdiri dari enam aspek yaitu pengetahuan atau ingatan, pemahaman, aplikasi, analisis, sintesis, dan evaluasi.

b. Ranah Afektif : berkenaan dengan hasil belajar sikap yang terdiri dari lima aspek yaitu penerimaan, jawaban atau reaksi, penilaian, organisasi dan internalisasi.

c. Ranah Psikimotorik : berkenaan dengan hasil belajar keterampilan dan kemampuan bertindak

Ketiga ranah tersebut menjadi objek penilaian hasil belajar. Diantara ketiga ranah itu, ranah kognitiflah yang paling banyak dinilai oleh para guru di sekolah karena berkaitan dengan kemampuan para siswa dalam menguasai isi bahan pengajaran. (Sudjana. 2004: 23)

Hasil belajar yang diperoleh biasanya berbeda antara siswa yang satu dengan yang lainnya. Perbedaan ini disebabkan oleh berbagai faktor, antara lain faktor kematangan, latar belakang pribadi masing-masing, sikap dan bakat terhadap suatu bidang pelajaran, jenis mata pelajaran, dan sebagainya.

Hasil belajar di dalam kelas dapat diterapkan kedalam situasi-situasi di luar sekolah. Dengan kata lain, siswa dapat dikatakan berhasil belajar bila ia dapat mentransfer hasil belajarnya kedalam situasi-situasi yang sesungguhnya di masyarakat.

Guru sebagai salah satu perancang kegiatan dalam belajar siswa di sekolah tentunya merujuk pada penataan kondisi dan situasi lingkungan sekolah yang mengarah pada terciptanya suasana belajar yang optimal bagi siswa. Belajar di sekolah dikatakan 
berhasil jika siswa dapat belajar secara optimal dan tercapainya tujuan belajar yang ditetapkan, dalam kondisi dan situasi sekolah yang diciptakan guru.

Guru mempunyai tanggung jawab yang besar dalam proses kegiatan belajar di sekolah, ini berarti setiap guru harus mengetahui hasil belajar setiap siswa, usaha untuk mengetahui hasil belajar siswa dilakukan dengan evaluasi.

Hasil belajar akan tercapai jika seseorang dapat mengubah tingkah lakunya, apabila tidak terdapat perubahan tingkah laku maka itu tidak dapat dikatakan hasil belajar. Perubahan tingkah laku tersebut dapat berbentuk kebiasaan, sifat-sifat, pengetahuan atau keterampilan. Hal ini dapat diperjelas oleh Arikunto dalam buku Dasardasar Evaluasi Pendidikan, yaitu :

"Dalam diri siswa terjadi perubahan tingah laku selama mengikuti program pengajaran, atau dengan kata lain perkataan-perkataan perubahan tingkah laku itu merupakan hasil dari adanya proses belajar mengajar. Oleh karena itu baik guru maupun siswa perlu mengetahui perubahan apakah yang telah terjadi pada waktu pengajaran, maka perlu adanya perumusan yang jelas bagi tujuan instruksional itu" (Arikunto. 2006: 135)

Perubahan-perubahan yang telah diuraikan di atas atau perubahan-perubahan yang terjadi itulah yang disebut hasil belajar. Hasil belajar dapat juga disebut tingkah laku. Karena belajar akan mendapatkan hasil yang berupa perubahan tingkah laku, jadi terbukti ada kesamaan kedua istilah di atas, yaitu hasil belajar dan tingkah laku.

Perubahan-perubahan itu dapat berupa suatu yang baru dan akan nampak/ terlihat dalam tingkah laku yang nyata atau dapat juga tingkah laku yang masih terselubung/ tidak terlihat. Bahkan perubahan dapat berupa penyempurnaan atas apa yang sudah dipelajari.

Berdasarkan uraian dan beberapa teori di atas, maka dapat disimpulkan bahwa yang dimaksud hasil belajar adalah pola-pola perubahan tingkah laku seseorang yang meliputi asfek kognitif, afektif dan psikomotor setelah menempuh kegiatan belajar tertentu yang tingkat kualitas perubahannya sangat ditentukan oleh faktor-faktor yang ada dalam diri siswa dan lingkungan sosial yang mempengaruhinya.

\section{Metode Tutor Sebaya}

Berbagai metode dapat digunakan untuk mengajarkan matematika, di antaranya dengan menggunakan metode tutor sebaya. Dengan interaksi belajar yang efektif siswa lebih termotivasi, percaya diri, mampu menggunakan strategi berpikir tingkat tinggi, serta mampu membangun hubungan interpersonal. (Masitoh dan Dewi. 2009: 233).

Sejak dini sebaiknya siswa sudah dilibatkan dalam proses pembelajaran matematika sesuai taraf perkembangan intelektualnya, sehingga anak akan memiliki konsep pengetahuan tentang matematika. Salah satu yang digunakan dalam pembelajaran matematika yaitu kemampuan berhitung.

Metode pembelajaran merupakan titik tolak atau sudut pandang kita terhadap proses pembelajaran terhadap proses pembelajaran. Nana Sudjana menegaskan bahwa metode yang digunakan guru dalam mengadakan hubungannya dengan siswa pada saat berlangsungnya pengajaran.

Guru yang menggunakan metode pembelajaran tutor sebaya mengacu kepada belajar kelompok siswa, menyajikan informasi baru kepada siswa setiap minggu menggunakan presentasi verbal atau teks. Guru membagi siswa menjadi kelompokkelompok kecil yang terdiri dari 4-5 orang dan terdiri laki-laki dan perempuan yang berasal dari berbagai suku, memiliki kemampuan cerdas, normal, dan lemah ( Daradjat. 2001:305). 
Metode tutor sebaya merupakan wahana penemuan dan pengembangan konsep. Di dalam proses pembelajaran terjadi interaksi antara siswa yang satu dengan siswa yang lain dalam memecahkan masalah yang diberikan oleh guru, sehingga terjadinya sikap meneliti, kreatif, tekun, kerjasama, kritis, tenggang rasa, objektif, bertanggung jawab, jujur, disiplin, dan original.

Dengan demikian metode tutor sebaya menekankan kepada kerjasama kelompok dan keterlibatan seluruh siswa dalam menghadapi tugas-tugas klasikal. Pada pembelajaran yang menggunakan kerja kelompok, seperti pada metode tutor sebaya biasanya guru dituntut untuk lebih selektif dalam menentukan kelompok.

Dalam pendekatan yang menggunakan kerjasama kelompok biasanya akan meningkatkan keakraban atau saling menyukai satu sama lain, dengan kata lain pendekatan kelompok seperti metode tutor sebaya dapat menumbuhkan rasa saling membutuhkan satu sama lain.

Keakraban kelompok ditentukan oleh beberapa faktor, yaitu:

1. Perasaan diterima atau disukai teman-teman

2. Tarikan kelompok

3. Partisipasi/ keterlibatan kelompok

4. Penerimaan tujuan kelompok dan persetujuan dalam cara penyampaiannya ( Djamarah, 2006:65)

Pada pembelajaran yang menggunakan kerja kelompok seperti metode tutor sebaya perlu menerapkan prinsip-pinsip sebagai berikut:

1. Siswa harus memiliki kejelasan tujuan, masalah, dan rencana yang jelas serta berarti baginya.

2. Setiap anggota harus memberikan kontribusi unruk menyelesaikan tugas.

3. Setiap anggota bertanggungg jawab kepada kelompoknya.

4. Prosedur pemecahan masalah harus dilakukan secara demokratis.

5. Setiap anggota merasa puas dan aman dalam belajar ( Sukarman. 2003: 27 ).

Beberapa pakar pendidikan menyatakan sepakat bahwa budi pekerti yang selama ini menjadi isu strategi dalam bidang pedidikan diajarkan secara terintegrasi dengan mata pelajaran di sekolah. Oleh karena itu dalam proses pembelajaran matematika, penggunaan pendekatan secara kelompok seperti metode tutor sebaya diharapkan dapat meningkatkan prestasi dan budi pekerti siswa.

Adapun yang mempengaruhi kualitas pengajaran terhadap hasil belajar terdiri dari 3 unsur yaitu:

1. Kompetensi guru, baik kognitif, sikap, dan perilaku. Termasuk kemampuan guru dalam menetapkan tujuan, memilih materi, memilih metode, menggunakan alat bantu, dan lain-lain yang merupakan komponen pengajaran.

2. Karakteristik kelas, yang termasuk di dalamnya besarnya kelas, suasana belajar dan fasilitas serta sumber belajar yang tersedia.

3. Karakteristik sekolah, yang berkaitan dengan disiplin sekolah, perpustakaan, dan sebagainya.

Kaitannya dengan hal peningkatan hasil belajar siswa, penggunaan metode tutor sebaya dapat mendorong prestasi siswa dan kemampuan siswa terhadap prinsip, nilai, dan proses pembelajran matematika sehingga tercipta adanya keseimbangan antara peningkatan kemampuan dan prosedural.

\section{METODE}

Metode penelitian yang digunakan adalah eksperimen, yaitu penelitian ini dilakukan dengan cara membandingkan (komparatif) kelas eksperimen dengan kelas kontrol. 
Kelas eksperimen adalah kelas yang diajarkan materi pengolahan data dengan menggunakan metode tutor sebaya, sedangkan kelas kontrol adalah kelas yang diajarkan materi yang sama dengan menggunakan metode ceramah.

\begin{tabular}{|c|c|}
\hline Eksperimen & Kontrol \\
\hline Y1 & Y2 \\
\hline
\end{tabular}

\section{Gambar 1. Desain Penelitian}

Keterangan :

Y1 : hasil belajar matematika yang diberikan metode tutor sebaya

Y2 : hasil belajar matematika yang diberikan metode ceramah

\section{HASIL DAN PEMBAHASAN}

\section{Analisis Statistik Deskriptif}

Berdasarkan perhitungan, maka rangkuman analisis statistik deskriptif dari variabel hasil belajar matematika dapat dilihat pada tabel di bawah ini :

Tabel 1. Rangkuman Statistik Deskriptif

\begin{tabular}{|c|c|c|}
\hline Statistik Deskriptif & $\begin{array}{c}\text { HBM Kelas Eksperimen } \\
\left(\mathbf{Y}_{\mathbf{1}}\right)\end{array}$ & $\begin{array}{c}\text { HBM Kelas Kontrol } \\
\left(\mathbf{Y}_{\mathbf{2}}\right)\end{array}$ \\
\hline $\mathrm{N}$ & 30 & 30 \\
\hline Mean & 7,10 & 5,53 \\
\hline Median & 6 & 5 \\
\hline Modus & 6 & 5 \\
\hline Varians & 2,96 & 3,92 \\
\hline Simpangan Baku & 1,72 & 1,98 \\
\hline
\end{tabular}

\section{Pengujian Persyaratan Data}

1. Uji Normalitas

Pengujian normalitas data menggunakan uji Liliefors dengan taraf siginifikan $\propto$ $=0,05$ dan $\mathrm{n}=30$.

Hipotesis pengujian :

$\mathrm{H}_{0}$ : data berdistribusi normal

$\mathrm{H}_{1}$ : data berdistribusi tidak normal

Kriteria pengujian :

Jika $\mathbf{L}_{\text {hitung }} \leq \mathbf{L}_{\text {tabel }}$ maka $\mathrm{H}_{0}$ diterima dan $\mathrm{H}_{1}$ ditolak

Jika $\mathbf{L}_{\text {hitung }}>\mathbf{L}_{\text {tabel }}$ maka $\mathrm{H}_{0}$ ditolak dan $\mathrm{H}_{1}$ diterima

Hasil pengujian normalitas data dapat dilihat pada tabel di bawah ini :

Tabel 2. Rangkuman Uji Normalitas Data

\begin{tabular}{|c|c|c|c|c|}
\hline Kelompok & $\mathbf{N}$ & $\mathbf{L}_{\text {hitung }}$ & $\mathbf{L}_{\text {tabel }}$ & Simpulan \\
\hline $\mathbf{Y}_{\mathbf{1}}$ & 30 & 0,148 & 0,161 & Data berdistribusi normal \\
\hline $\mathbf{Y}_{\mathbf{2}}$ & 30 & 0,154 & 0,161 & Data berdistribusi normal \\
\hline
\end{tabular}

2. Uji Homogenitas

Pengujian homogenitas antara kelompok eksperimen dan kelompok kontrol dilakukan dengan uji Fisher.

Hipotesis pengujian :

$\mathrm{H}_{0}$ : kedua kelompok data homogen 
$\mathrm{H}_{1}$ : kedua kelompok data tidak homogen

Kriteria pengujian :

Jika $\mathbf{F}_{\text {hitung }} \leq \mathbf{F}_{\text {tabel }}$ maka $\mathrm{H}_{0}$ diterima dan $\mathrm{H}_{1}$ ditolak

Jika $\mathbf{F}_{\text {hitung }}>\mathbf{F}_{\text {tabel }}$ maka $\mathrm{H}_{0}$ ditolak dan $\mathrm{H}_{1}$ diterima

Hasil pengujian normalitas data dapat dilihat pada tabel di bawah ini :

Tabel 3. Rangkuman Uji Homogenitas Data

\begin{tabular}{|c|c|c|c|}
\hline Kelompok & $\mathbf{F}_{\text {hitung }}$ & $\mathbf{F}_{\text {tabel }}$ & Simpulan \\
\hline $\mathbf{Y}_{\mathbf{1}} \& \mathbf{Y}_{\mathbf{2}}$ & 1,32 & 1,86 & Kedua kelompok data homogen \\
\hline
\end{tabular}

\section{Pengujian Hipotesis}

Pengujian hipotesis menggunakan uji-t dengan taraf signifikan $\alpha=0,05$. Berdasarkan perhitungan, diperoleh nilai-nilai sebagai berikut :
$\mathrm{n}_{1}=30$
$\mathrm{n}_{2}=30$
$\mu_{2}=5,53$
$\mu_{1}=7,10$
$\mathrm{s}_{2}=3,92$
$\mathrm{s}_{\mathrm{gab}}=1,85$
$\mathrm{s}_{1}=2,96$

$$
\mathrm{s}_{2}=3,92
$$

Hipotesis pengujian :

$\mathrm{H}_{0}: \mu_{1} \leq \mu_{2}$

$\mathrm{H}_{1}: \mu_{1}>\mu_{2}$

Kriteria pengujian :

Jika $\mathbf{t}_{\text {hitung }} \leq \mathbf{t}_{\text {tabel }}$ maka $\mathrm{H}_{0}$ diterima dan $\mathrm{H}_{1}$ ditolak

Jika $\mathbf{t}_{\text {hitung }}>\mathbf{t}_{\text {tabel }}$ maka $\mathrm{H}_{0}$ ditolak dan $\mathrm{H}_{1}$ diterima bawah ini :

Rangkuman hasil pengujian hipotesis penelitian dapat dilihat pada tabel di

Tabel 4. Rangkuman Uji Hipotesis Penelitian

\begin{tabular}{|c|c|c|c|}
\hline Kelompok & $\mathbf{t}_{\text {hitung }}$ & $\mathbf{t}_{\text {tabel }}$ & Simpulan \\
\hline $\mathbf{Y}_{\mathbf{1}} \boldsymbol{\&} \mathbf{Y}_{\mathbf{2}}$ & 1,805 & 1,679 & $\mathrm{H}_{0}$ ditolak dan $\mathrm{H}_{1}$ diterima \\
\hline
\end{tabular}

\section{Pembahasan}

Berdasarkan nilai tersebut maka diperoleh nilai $t_{\text {hitung }}>t_{\text {tabel }}$. Hal ini menyatakan bahwa $\mathrm{H}_{1}$ diterima sehingga dapat disimpulkan ada perbedaan hasil belajar matematika siswa antara kelas yang menggunakan metode tutor sebaya dengan kelas menggunakan metode klasik. kelompok siswa yang diajar dengan pemberian metode tutor sebaya terhadap hasil belajar matematika siswa.

Penggunaan metode tutor sebaya dalam proses pembelajaran bisa menjadi pilihan dalam mengajarkan matematika di sekolah, karena berpengaruh terhadap hasil belajar matematika siswa. Selain mudah untuk diterapkan dalam proses pembelajaran yaitu dengan cara guru membagi siswa dengan beberapa kelompok yang setiap kelompok terdiri dari 4-5 siswa. Setiap kelompok ada satu orang yang bertugas menjadi tutor pada temannya. Yang menjadi tutor adalah siswa yang mendapat ranking 10 besar di kelas. Metode tutor sebaya memberikan motivasi siswa untuk belajar kognitif, afektif, dan psikomotorik, sehingga hasil belajar siswa meningkat secara optimal.

\section{PENUTUP}

\section{Simpulan}

Dengan menelaah data - data yang telah di paparkan di atas, penulis dapat mengambil satu kesimpulan yang didapat dari hasil pengujian hipotesis. Yaitu terdapat pengaruh metode tutor sebaya terhadap hasil belajar siswa.Hasis belajr siswa dengan menggunakan metode Totor Sebaya meningkat,sehingga dapat menjadi metode yang 
digunakan oleh guru dalam memberikan pelajaran Matematika yang perlu mendapat dukungan dari semua pihak terkait yang berkompeten,terutama dari Kepala Sekolah,siswa dan para orangtua siswa sehingga dalam pelaksanaanya dapat terlaksana secara efektif.

\section{Saran}

Saran yang dapat penulis kemukakan adalah perlu adanya peranan orang tua dalam proses pembelajaran siswa dan perlu juga adanya penggunaan metode - metode penunjang serta sarana yang memadai dalam proses pembelajaran, yang nantinya akan meningkatkan hasil dari belajar tersebut. Selain itu dalam pembelajaran matematika siswa diarahkan dan dipantau perkembangannya agar materi yang diajarkan dapat terserap dengan baik oleh siswa.

\section{DAFTAR PUSTAKA}

A. Tafsir dan Nursobar, Asep. 2009. Filsafat dan Metode berpikir. Jakarta: Direktorat Jenderal Pendidikan Islam Departemen Agama Republik Indonesia.

Arikunto, Suharsimi. 2006. Dasar-Dasar Evaluasi Pendidikan. Jakarta: Bumi Aksara. Daradjat, Zakiah, dkk. 2001. Metodik Pengajaran Agama Islam. Jakarta: Bumi Aksara. Masitoh dan Dewi, Laksmi. 2009. Strategi Pembelajaran. Jakarta: Direktorat Jenderal Pendidikan Islam Departemen Agama Republik Indonesia.

Rakhmat, Jalaludin. 2000. Metode Penelitian Komunikasi. Penerbit: PT Remaja Rosdakarya offset Bandung.

Sadullah, Uyoh. 2009. Paedagogik. Jakarta: Direktorat Jenderal Pendidikan Islam Departemen Agama Republik Indonesia.

Safari. 2005. Statistika. Sidoarjo: Masmedia Buana Pustaka.

Sanjaya, Wina. 2008. Strategi Pembelajaran Berorientasi Standar Proses Pendidikan. Jakarta: Kencana Prenada Media Group.

Sudjana, Nana. 2005. Metoda Statistika. Bandung: PT Remaja Rosdakarya.

Suprijono, Agus. 2011. Cooperative Learning: Teori dan Aplikasi PAIKEM. Yogyakarta: Pustaka Pelajar.

Susetyo, Budi. 2009. Statistika. Jakarta: Direktorat Jenderal Pendidikan Islam Departemen Agama Republik Indonesia.

Sutarsih, Cicih. 2009. Etika Profesi. Jakarta: Direktorat Jenderal Pendidikan Islam Departemen Agama Republik Indonesia.

Syah, Darwyan. 2009. Strategi Belajar Mengajar. Jakarta: Diadit Media.

Syah, Darwyan. 2009. Penilaian hasil proses belajar Mengajar. Bandung: PT Remaja Rosdakarya.

\section{Internet}

http:// safir.com/2012/08/ Macam-Macam Metode-Mengajar

http:// ebook Uji Instrumen Penelitian. Diunduh 7-05-2013

http:// Penelitian Tutor Sebaya. Diunduh 7-05-2013 